\title{
EMPLOYMENT AND DEADWEIGHT LOSS EFFECTS OF OBSERVED NON-WAGE LABOR COSTS
}

\author{
Giovanna Aguilar y Sílvio Rendon \\ Junio, 2007
}

DOCUMENTO DE TRABAJO 259

http://www.pucp.edu.pe/economia/pdf/DDD259.pdf 


\title{
EMPLOYMENT AND DEADWEIGHT LOSS EFFECTS OF OBSERVED NON- WAGE LABOR COSTS
}

\author{
Giovanna Aguilar \\ Pontificia Universidad Católica del Perú \\ Sílvio Rendon \\ Instituto Tecnológico Autónomo de México (ITAM)
}

\begin{abstract}
RESUMEN
Para evaluar el efecto de los costos laborales sobre el empleo es crucial tener estimaciones confiables de la elasticidad costo laboral de la demanda de trabajo. Usándose una base de datos emparejados a nivel de firmas y trabajador, estimamos una función de demanda no condicionada de trabajo de largo plazo, explotando información sobre trabajadores para corregir la endogeneidad en la determinación de los salarios. Evaluamos los efectos sobre el empleo y la pérdida de eficiencia social de los valores observados de las aportaciones de los empleadores impuestas por la legislación laboral (seguro de salud, capacitación e impuestos) así como de las deducciones a los trabajadores (seguridad social e impuesto a la renta). Encontramos que los costos laborales no salariales reducen el empleo en $17 \%$ para los empleados y en 53\% para los obreros, con pérdidas de eficiencia social asociadas de $10 \%$ y $35 \%$ del total de la recaudación, respectivamente. Desde que muchas firmas subcumplen con las aportaciones y descuentos legales, encontramos que el cumplimiento de la ley implicaría una pérdida de $4 \%$ de empleo en el caso de los empleados y de $12 \%$ para el caso de obreros, con una respectiva pérdida de eficiencia social de $2 \%$ y $6 \%$.
\end{abstract}

\begin{abstract}
To assess the employment effects of labor costs it is crucial to have reliable estimates of the labor cost elasticity of labor demand. Using a matched firm-worker dataset, we estimate a long run unconditional labor demand function, exploiting information on workers to correct for endogeneity in the determination of wages. We evaluate the employment and deadweight loss effects of observed employers' contributions imposed by labor laws (health insurance, training, and taxes) as well as of observed workers' deductions (social security and income tax). We find that non-wage labor costs reduce employment by $17 \%$ for whitecollars and by $53 \%$ for blue-collars, with associated deadweight losses of $10 \%$ and $35 \%$ of total contributions, respectively. Since most firms undercomply with mandated employers' and workers contributions, we find that full compliance would imply employment losses of $4 \%$ for white-collars and $12 \%$ for blue-collars, with respective associated deadweight losses of $2 \%$ and $6 \%$.
\end{abstract}




\title{
EMPLOYMENT AND DEADWEIGHT LOSS EFFECTS OF OBSERVED NON- WAGE LABOR COSTS*
}

\author{
Giovanna Aguilar \\ Pontificia Universidad Católica del Perú \\ Sílvio Rendon \\ Instituto Tecnologico Autónomo de México (ITAM)
}

\section{INTRODUCTION}

Non-wage labor costs consist of several mandated benefits, health, training, accident, housing plans, as well as several taxes, and are intended to increase workers' welfare and job security. However, these benefits tend to come at the expense of reducing employment and deadweight losses. In order to quantify these resulting effects one needs a reliable measure of the employment-labor cost elasticity. Most studies conducted on this subject find low estimated values for this elasticity, which contrasts with policy-makers' enthusiasm to reduce labor costs.

In this article, using a Peruvian matched firm-workers dataset, we find that non-wage labor costs reduce employment measured in total hours of work by $17 \%$ for white-collars and by $53 \%$ for blue-collars with associated deadweight losses of $10 \%$ and $35 \%$ of total contributions' revenues, respectively. We also compute employment losses of compliance with mandated employers' and workers contributions of $4 \%$ for white-collars and $12 \%$ for blue-collars, with respective associated deadweight losses of $2 \%$ and $6 \%$ of contribution revenues.

These results come from estimating the long run unconditional firm-level labor demand function by a procedure that corrects for endogeneity of wages. We show that unbiased estimates, even using small units such as firm level data, require not only that wages are exogenous, but also that their unobserved determinants are uncorrelated with the unobserved determinants of labor demand. This requirement is not fulfilled in the likely

Our emails: gaguila@pucp.edu.pe, srendon@itam.mx. We thank Cecilia Garavito, Daniel Hamermesh, Miguel Jaramillo and participants of the LACEA-LAMES Meetings in Mexico, the Second Meetings of Labor Economics in Lima, and seminars at the Universidad Católica of Perú and ITAM, for their comments and suggestions. We also thank Ramón Díaz for outstanding research assistance. Financial support of the Universidad Católica of Perú and of the Asociación Mexicana de Cultura is gratefully acknowledged. All errors and omission are only ours. 
event that larger firms are matched with more productive workers. Consequently, an estimation that corrects for endogeneity yields a larger labor cost elasticity of labor demand than one that does not, like OLS.

In the last two decades, there has been intensive theoretical and empirical research on the effects of labor market frictions on job creation. Western European economies, characterized by large job security provisions, have been the center of attention of this research that has modeled these frictions as adjustment costs in labor demand (Nickell 1987, Hamermesh 1989, Bentolila and Bertola 1990, Hopenhayn and Rogerson 1993, Rendon 2000). This literature finds that the effects of 'eurosclerosis,' that is, labor markets with high firing costs, are ambiguous: in good times, sclerotic labor markets create fewer jobs than free labor markets; however, in bad times, sclerotic labor markets reduce job destruction. Most of the research done in Latin America has been done under these guidelines, obtaining statistically significant negative effects of job security provisions on employment rates. ${ }^{1}$ Furthermore, using country-level data for Latin America and OECD countries Heckman and Pagés-Serra (2000) found large effects of job security provisions on employment, ${ }^{2}$ which are robust to several specifications, OLS, random and fixed effects. The authors present their results as a strong evidence against Freeman's (2000) view that job security regulations mostly affect distribution, but not efficiency, and "advocate the substitution of job security provisions by other mechanisms that provide income security at lower efficiency and inequality costs." Under a classic labor demand framework and using workers- and firmlevel data, this article provides new evidence in the same direction, extending the computation of the effects of job security provisions to deadweight losses.

Hamermesh (1993) surveys several studies on the estimation of labor demand and remarks that estimates of the labor-cost employment elasticity should be interpreted and compared cautiously depending on the specification adopted: whether capital is included as an explanatory variable in the estimation (if so one is estimating a short run labor demand; if

1 As referred by Heckman and Pagés-Serra (2000, Table 2 and footnote 6), many of the research projects that provide this empirical evidence (for instance Márquez and PagésSerra 1998 or Saavedra and Torero 2000) were evaluations of the labor reforms that reduced non-wage labor costs Latin America and sponsored by a Inter-American Bank's research network coordinated by Heckman and Pagés-Serra.

2 In particular, for Peru, where our data come from, research done so far on the demand for labor finds very low labor costs elasticities of labor demand: $-\eta_{L, w} \in[0.10,0.65]$ (Rendón and Barreto 1992, IPE 1998, Chacaltana 1999, MTPE 1999, 2004, Jaramillo 2004). 
not, it is a long run labor demand); whether output is included in the estimation (if it is, one is estimating a conditional labor demand; if not, an unconditional labor demand); whether one is estimating a system of equation and thus controlling for endogeneity of wages (in which case one will typically find larger estimates). In our study we assume homogeneous labor and make two separate estimations for white- and blue-collar workers without allowing for interactions between them. Since our study is done for small units, at the firm level, it is a reasonable assumption that firms face a horizontal labor supply. However, assortative matching between firms and workers gives rise to correlation between wages and firm size, which calls for a correction of this endogeneity. Capital is not included in the estimation, nor output, which makes the estimation a long run, non-conditional labor demand estimation, that is, the scale effect is included in the total effect captured by our estimated elasticity. These features of our research explain why we find larger labor costs elasticities of employment ${ }^{3}$ estimates usually found for the standard specification of a conditional labor demand. ${ }^{4}$ Our results are thus encouraging of policies for stimulating job creation by inducing movements along as well as shifts of the labor demand curve.

The remainder of this article is organized as follows. The next section details our estimation approach which addresses the issue of endogeneity correction; Section 3 describes the dataset used, as well as descriptive statistics. Section 4 discusses the resulting estimated labor-cost employment elasticities obtained by OLS and by an IV estimation, both for legal and for observed non-wage labor costs. In Section 5 we compute the employment reduction caused by workers' and employers' contributions. Section 6 reports the calculated deadweight losses of workers' and employers' contributions as a proportion of contribution revenues. Section 7 reports the employment and deadweight losses of complying fully with legal workers' and employers' contributions. Finally, Section 8 summarizes the article's main conclusions.

3 Another important source of underestimating the labor cost elasticity of employment is the presence of measurement error combined with the assumption of homogeneity of labor (Clark and Freeman 1980, Roberts and Skoufias1997).

$4 \quad$ Unlike most studies, however, we use observed rather than legal non-wage labor costs and avoid thereby an overestimation of the labor-cost employment elasticity. 


\section{ESTIMATION APPROACH}

Consider a static setup where a firm $i \in\{1,2, \ldots, N\}$ chooses inputs to maximize profits: $\max _{K, L}\left\{p_{i} f\left(K_{i}, L_{i} \mid \Omega_{i}\right)-r_{i} K_{i}-w_{i}^{a} L_{i}\right\}$. The resulting demand for labor is given by the function $L_{i}=L\left(w_{i}^{a} \mid X_{i}{ }^{*}\right)$ where $w_{i}^{a}$ is the total labor cost paid by the firm and $X_{i}^{*}=\left\{p_{i}, r_{i}, \Omega_{i}\right\}$ represents output and input prices and the parameters of the production function for the firm. A log-linear approximation to this function is

$$
\ln L_{i}=\beta \ln w_{i}^{a}+X_{i} \delta+u_{i}
$$

where $X_{i}$ are those variables contained in $X_{i}^{*}$ that are observed by the researcher, whereas $u_{i}$ is a random variable representing the unobserved components of $X_{i}^{*}$, assumed to be normal with zero mean and variance $\sigma_{u}^{2}$.

If wages are fully exogenous, that is, if $\ln w_{i}^{a}$ is uncorrelated with $u_{i}$, then one can obtain an unbiased and consistent estimation of $\beta$ by OLS. For this assumption to hold, wages have to be determined by an infinitely elastic labor supply. Actually, most empirical research, assumes exogenous wages and estimates the elasticity labor- labor cost by OLS. This includes those estimations that account for individual (fixed) effects when panel data are available.

To illustrate this assertion, let the infinitely elastic labor supply of individual $j \in\{1$, $\left.2,3, \ldots M_{i}\right\}$ related to firm i be

$$
\ln w_{i j}^{d}=Z_{i j} \gamma+v_{i j}
$$

where $w_{i j}{ }^{d}$ is the take-home wage, $Z_{i j}$ is a vector of covariates that determine wages, $\gamma$ are its associated parameters, and $v_{i j}$ is a random variable of unobservables with zero mean, variance $\sigma_{v}{ }^{2}$ and covariance with $u_{i}$ equal to $\sigma_{u v}$. This is a reduced form equation that can be though of as a Mincer equation in which $Z_{i j}$ only include supply-side variables, such as education, ${ }^{5}$ tenure, experience, and individual workers' attributes. ${ }^{6}$ Then firm $i$ faces a labor supply function:

5 Unfortunately, our dataset does not include any variable that could possible proxy workers' education. 


$$
\ln w_{i}^{d}=Z_{i} \gamma+v_{i}
$$

where $\ln w_{i}^{d}=M_{i}^{-1} \sum \ln w_{i j}^{d}, Z_{i}=M_{i}^{-1} \sum Z_{i j}$, and $v_{i}=M_{i}^{-1} \sum v_{i j}$ is distributed with mean 0 , variance $M_{i}^{-1} \sigma_{v}^{2}$, and covariance with $u_{i}$ equal to $\sigma_{u v}$. Assume for the moment that wages paid by employers coincide with workers' take-home wages: $w_{i}^{d}=w_{i}^{a}$, then, as this is a recursive or limited information estimation model, OLS estimates yield unbiased estimates of the labor demand parameters. The crucial assumption for this to be true is that the firm's individual labor supply is infinitely elastic and error terms are independent, $\sigma_{u v}=0$.

However, it may well be the case that $\sigma_{u v} \neq 0$ which implies that $w_{i}^{a}$ and $u_{i}$ are correlated and the estimation by OLS generates biased estimates. Moreover, if $\sigma_{u v}>0$, that is, if unobservables that increase wages are positively correlated with unobservables that increase labor demand, then $\beta$ estimated by OLS will exhibit an upward bias. One can think of this positive correlation as evidence for positive assortative matching between firms and workers: more productive workers are matched to larger firms. Or, in terms of the variables that are unobserved to the researcher, workers' of higher ability may work in firms of higher total factor productivity. On the contrary, $\sigma_{u v}<0$ is associated with unobservables that increase wages negatively correlated with unobservables that increase labor demand, in which case OLS leads to underestimate $\beta$. Therefore, that is the case of negative assortative matching between firms and workers: more productive workers are matched to smaller firms. $^{7}$

$6 \quad$ If $Z_{i j}$ Eq. (2) includes labor demand variables that are excluded in Eq. (1), then it becomes a typical reduced form and one can attempt to identify not only the labor demand labor cost elasticity, but also the labor supply labor cost elasticity. We leave this extension for future research.

7 Or, when employment is measured by individual hours of work, it is likely to find negative matching: more productive workers are matched to firms with fewer individual hours of work, as shown in Section 4. 
Figure 1: Labor Supply and Demand

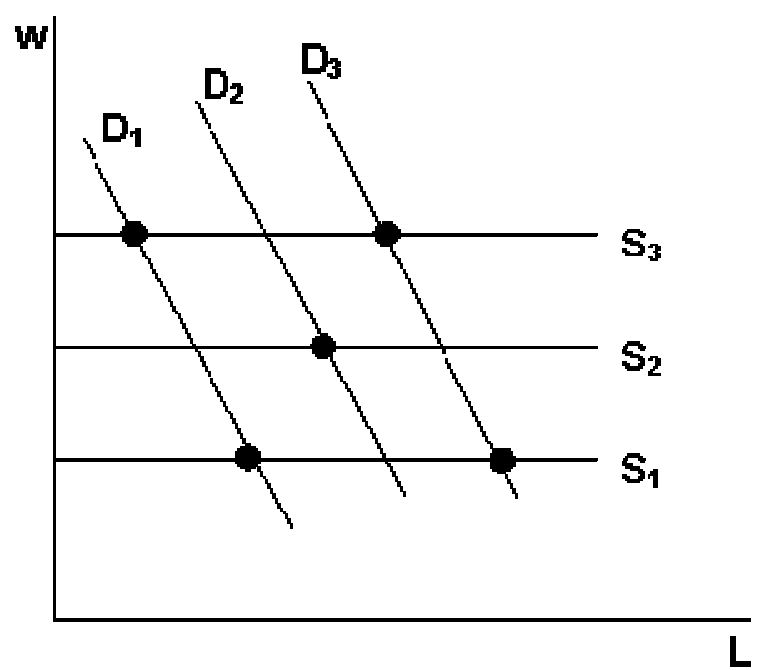

Figure 1 depicts the supply and demand for labor and illustrates this matching effect: if $D_{1}$ is matched to $S_{1}, D_{2}$ to $S_{2}$, and $D_{3}$ to $S_{3}$, then the resulting equilibrium points describe a positive relationship or a negative relationship that is steeper than the labor demand (overestimation of $\beta$ ); if matching between supply and demand is the other way round, negative, the relationship resulting from the equilibrium points is flatter than the labor demand (underestimation of $\beta$ ).

Now, let us allow labor costs paid for by employers differ from workers' take-home wages. Suppose that employers' contributions expressed as a percentage of wages are $\mathrm{a}_{\mathrm{i}}$, so that employers' labor costs are $w_{i}^{a}=w_{i}\left(1+a_{i}\right)$. On the other hand, let $d_{i}$ be workers' contributions as a percentage of wages, and workers' take home wage is then $w_{i}^{d}=w_{i}\left(1-d_{i}\right)$. Under the assumption that both employer- and worker-paid contributions are unrrelated to unobservables that determine firm's size ${ }^{8}$ one can relate employers' labor costs to workers' earnings simply by

$$
\ln w_{i}^{a}=\ln w_{i}^{d}-\ln \left(1-d_{i}\right)+\ln \left(1+a_{i}\right)
$$

In this article, we take under compliance as given and only analyze its effects on employment and measurement of the labor-cost elasticity; however, strictly speaking under complying is also a decision made by employers, which therefore would require a specific theoretical and empirical analysis. 
Notice that if wages are fully exogenous, ${ }^{9}$ under no circumstance workers earn below $\ln w_{i}{ }^{d}$, which implies that workers' contributions are actually paid for by employers. In particular, if workers' contributions were reduced, employer-paid wages would adjust so that workers' take-home wages are left unchanged. This feature of the labor market will be important when analyzing the employment effects of removing workers' and employers' contributions.

Under this setup we can propose the following estimation procedure:

1. First Stage: Estimate Eq. (2), predict the workers' take-home wage, aggregate ${ }^{10}$ them to $\hat{\ln } w_{i}^{d}=\mathrm{Z}_{\mathrm{i}} \hat{\gamma}$, and use it to predict the total labor cost paid by the employer $\hat{\ln } w_{i}^{a}$ from Eq. (4)

2. Second Stage: Estimate Eq. (1) using the predicted employers' labor cost $\ln w_{i}^{a}$.

This estimation procedure removes the correlation between labor costs paid for by employers and the disturbance term in Eq. (1) and yields unbiased estimates of $\beta$ and $\delta$.

To implement this estimation we need firm-level data matched with data on individuals working at the firm. In the next section, we describe the data used in the estimation.

\section{DATA}

The data used in this estimation come from the Wage and Salary National Survey (ENSYS) carried out by the Ministry of Labor of Peru. This is a biquarterly survey applied in June and December, which comprises private firms of 10 and more workers and is representative for the main cities (Metropolitan Lima and urban areas of 24 main cities in the country), economic sectors and activities, and firms sizes in Peru. The information for this

9 This is an important identification assumption, the labor supply is horizontal to the market, which makes feasible the determination of the labor cost elasticity of the labor demand. This assumption does not hold if the labor supply is horizontal to the firm, but not to the market, as aggregation does not preserve the horizontal labor supply.

10 When employment is measured by individual hours of work and, consequently, one is estimating an individual labor demand, there is no need to perform this aggregation. 
survey is gathered by qualified interviewers from the Labor Ministry who review firms' payrolls and are specialized in labor costs in Peru; thus, this survey does not consist of selfreported data.

The survey is organized in three sections. Section A aggregate firm-level information such as the total number of workers, wages by occupational category, total hours worked, legal workers' deductions and employers' contributions by occupational category. Section B contains information on a sample of individual workers inside the firm, with variables such as age and gender of the worker, hours worked, basic wage or salary, legal workers' deductions and employers' contributions, and other nonpermanent payments. Finally, Section $\mathrm{C}$ provides information on collective bargaining and unionization of workers.

We use the survey for June 2004, which consists of a sample of 1,772 firms, for which we have 19,770 workers. Because we concentrate on the demand for white- and bluecollar workers, we select two subsamples of firms that hire at least one of these two types of workers. Thus, the resulting samples contain respectively 1,714 firms with 13,097 whitecollar workers, and 692 firms with 5,413 blue-collar workers. 
Table 1. Descriptive Statistics for White- and Blue-collar workers Firm and Worker Samples. Standard errors in small fonts

\begin{tabular}{|c|c|c|c|c|}
\hline \multirow{2}{*}{ Workers Survey's Section } & \multicolumn{2}{|c|}{ White-collar } & \multicolumn{2}{|c|}{ Blue-collar } \\
\hline & Firm & Worker & Firm & Worker \\
\hline \multirow[t]{2}{*}{ Hours of work } & 44.5 & 446.1 & 42.9 & 45.8 \\
\hline & 6.4 & 7.5 & 7.7 & 9.6 \\
\hline \multirow[t]{2}{*}{ Employment } & 99.80 & & 128.4 & \\
\hline & 300.9 & & 297.5 & \\
\hline \multirow[t]{2}{*}{ Wages } & 542.2 & 605.0 & 232.9 & 246.2 \\
\hline & 477.0 & 668.5 & 188.3 & 386.1 \\
\hline \multicolumn{5}{|l|}{ Employers'contributios (\% of wage) } \\
\hline \multirow[t]{2}{*}{ Observed } & 10.2 & 10.3 & 10.7 & 10.9 \\
\hline & 1.4 & 1.4 & 3.6 & 4.8 \\
\hline \multirow[t]{2}{*}{ Legal } & 14.5 & 14.5 & 14.5 & 14.5 \\
\hline & 0.0 & 0.0 & 0.0 & 0.0 \\
\hline \multicolumn{5}{|l|}{ Workers's contributions ( $\%$ of wage) } \\
\hline \multirow[t]{2}{*}{ Observed } & 15.7 & 14.9 & 11.99 & 11.8 \\
\hline & 4.8 & 5.5 & 2.3 & 2.7 \\
\hline \multirow[t]{2}{*}{ Legal } & 17.8 & 18.0 & 13.1 & 13.3 \\
\hline & 6.0 & 6.5 & 3.2 & 3.6 \\
\hline \multicolumn{5}{|l|}{ Economic Sector } \\
\hline Primary & 6.4 & 4.8 & 10.3 & 13.7 \\
\hline Industry & 23.4 & 18.7 & 48.3 & 56.5 \\
\hline Services & 70.2 & 76.6 & 41.5 & 29.9 \\
\hline \multicolumn{5}{|l|}{ Firm size } \\
\hline$\leq 50$ & 62.2 & 30.9 & 50.9 & 19.7 \\
\hline $51-99$ & 13.1 & 19.2 & 13.4 & 13.4 \\
\hline$\geq 100$ & 24.7 & 49.9 & 35.7 & 66.9 \\
\hline Lima Met & 48.6 & 55.6 & 42.8 & 46.9 \\
\hline Union & 8.2 & 13.6 & 15.0 & 20.0 \\
\hline Women & & 37.4 & & 14.0 \\
\hline \multirow{2}{*}{ Age } & & 37.8 & & 37.4 \\
\hline & & 10.2 & & 11.1 \\
\hline$\leq 24$ & & 4.1 & & 8.4 \\
\hline $25-45$ & & 72.3 & & 66.7 \\
\hline$>45$ & & 23.7 & & 25.0 \\
\hline \multirow[t]{2}{*}{ Tenure } & & 6.1 & & 6.0 \\
\hline & & 7.4 & & 8.1 \\
\hline$<3$ & & 46.9 & & 53.6 \\
\hline $3-8$ & & 29.2 & & 22.7 \\
\hline$>8$ & & 23.9 & & 23.7 \\
\hline Nobs. & 1714 & 13097 & 692 & 5413 \\
\hline
\end{tabular}


Table 1 shows the descriptive statistics for all variables in the final sample, divided by type of worker and by section of the survey. For several variables there are both firm-level as well as individual information. Understandably, there is more dispersion for information in the workers' sample (Section B). Both white- and blue-collar workers work on average more than 40 hours a week. On average, blue-collar workers work in firms that are $30 \%$ larger than white-collars and earn half as much as white-collars.

Figure 2: Employers and Workers' contributions as a percentage of wages for White-collar and Blue-Collar Workers.
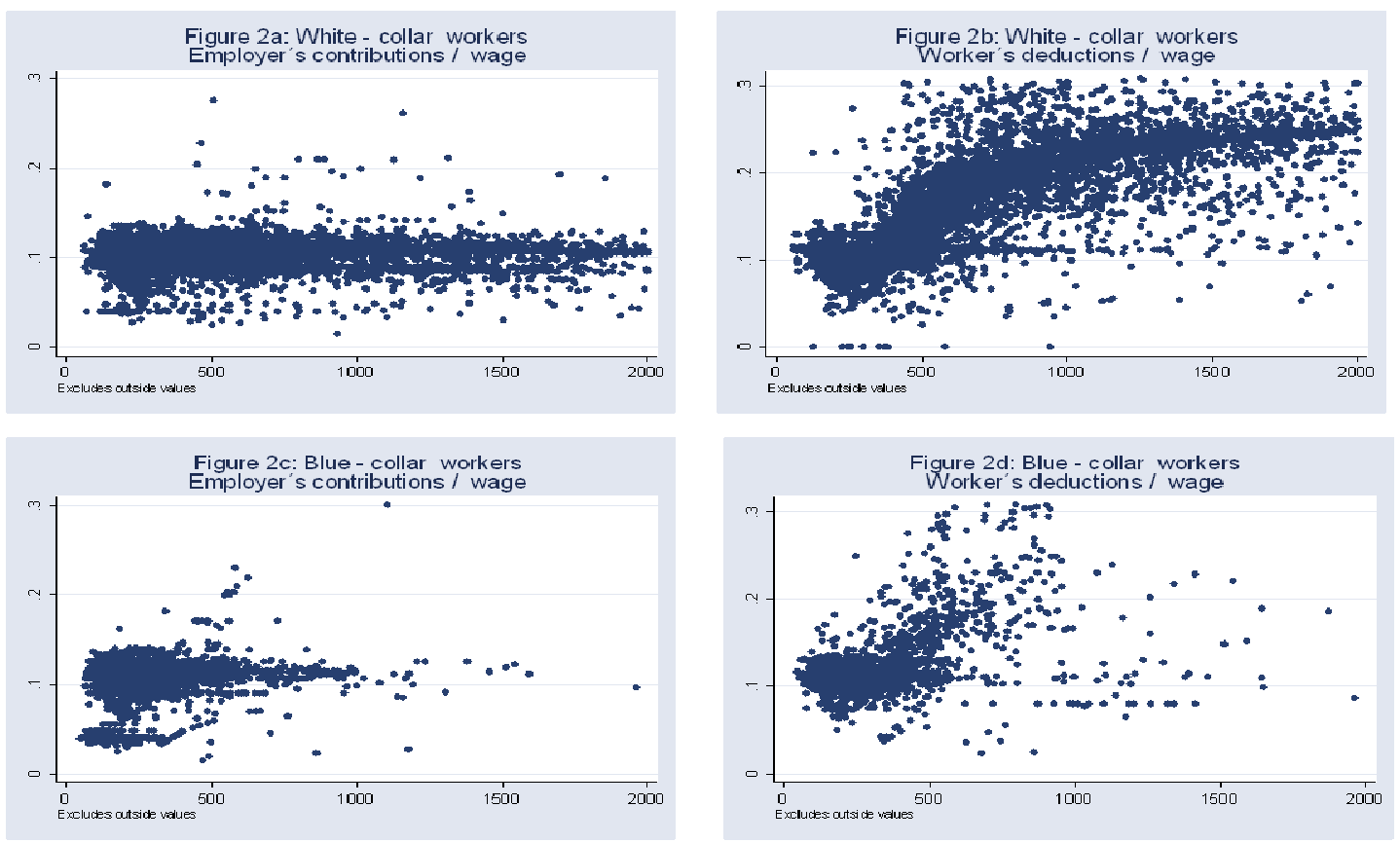

In this study, gross wages are defined as payments made by employers to their employees for their work that end up in employees' paychecks, including any mandatory benefits, ${ }^{11}$ before deductions for income taxes and pension contributions are applied. Workers' contributions are mandatory payments deducted from workers' paychecks, that is, pension contributions and income taxes. Employers' contribution are payments associated with workers' wages that employers pay and workers do not take home nor are deducted from workers' gross wages, but go to several funds, such as health or training systems, and

11 These definitions are important because many other studies confuse mandatory benefits that workers take home, such as vacations' payments, which here are considered as part of wages, with non-wage labor costs paid for by employers. 
payroll taxes. ${ }^{12}$ Both observed employers' and workers' contributions are on average lower than legal ones, i.e., undercompliance is predominant. ${ }^{13}$ Observed employers' contribution are between $10 \%$ and $11 \%$ of wages for all samples, while legal contributions are established at $14.5 \%$. For white-collars observed workers' contributions are between $15 \%$ and $16 \%$ of wages, while the legal contributions are around 18\%; for blue-collars observed workers' contributions are around $12 \%$ of wages, while legal contributions are set at around $13 \%$. Figure 2 shows the employers' contributions and workers' deductions as a function of wages, both for white- and blue-collar workers. For employers' contributions one can distinguish a dispersion around horizontal lines, because legal contributions are a fixed percentage that does not depend on wage levels. However, the dispersion of workers' deductions occurs around both increasing curves and horizontal lines, as some deductions are increasing in wages, income taxes, while others are fixed, pensions' contributions. Moreover, there is compliance with some contributions and not with others, which explains why one can distinguish several patterns in these graphs, which are illustrative of the important differences between legal and observed non-wage labor costs.

In the subsample of white-collars, around $70 \%$ of firms and $77 \%$ individuals are occupied in the service sector; whereas in the subsample of blue-collars around $50 \%$ of firms and $57 \%$ of individuals are classified as part of the industrial sector. For both subsamples most firms are small, more than $50 \%$ employ 50 workers or less; however, more than $50 \%$ of workers work in firms with 100 or more workers. Around half of firms are located in Lima City, the capital of the country. Unionization is higher for blue-collar workers with rates between $15 \%$ and $20 \%$ of workers, while for white-collars unionization rates are between $8 \%$ and $14 \%$.

In terms of individual data we find that $38 \%$ are females among the white-collars while only $14 \%$ among the blue-collars. On average both white- and blue-collars are around 38 years old, however among blue-collars there is more age dispersion especially at the lower tail: around $12 \%$ of blue-collars, against only $4 \%$ of white collars, are 24 years old or

12 Thus employers' and workers' contributions are non-wage labor costs. The former displace the demand and the latter the supply of labor. Unlike other studies which only focus on employers' non-wage labor costs, both types of non-wage labor costs matter in reducing employment. Interestingly, from an economic point of view, as said before, if the labor supply is fully elastic, all non-wage labor costs are paid for by employers.

13 The interested reader will find a brief explanation of the labor reforms in Peru in the nineties in Appendix A1 and a detailed description of non-wage labor costs in Appendix A2. 
younger. In the samples both white- and blue-collars have on average around 6 years of tenure; however, in tenure it is blue collars who also exhibit more dispersion, especially at the lower tails. While $23 \%$ of white-collars have around less than one year of tenure, $29 \%$ of blue-collars have tenure of less than one year.

In the next sections, we present the results of estimating a labor demand model both by simple OLS and controlling for the endogeneity of wages.

\section{ESTIMATION RESULTS}

In this section, we present the elasticities estimated by the procedure described in Section 2. We estimate several versions of the model, the results of which are presented in Table 2. For the total hours of work and for the number of workers, we report in the first column an OLS estimation using the average wage reported in the firm level information, in the second column an OLS estimation using an average wage constructed using the individual information, and in the third column an estimation that accounts for endogeneity, an OLS estimation using the average of a predicted wage. For individual hours, we report OLS and IV results in the first and second columns, respectively. 
Table 2. Estimated wage-elasticities of demand for labor measured as total hours, workers, and individual hours. Standard errors in small fonts

\begin{tabular}{|c|c|c|c|c|c|c|c|c|}
\hline & \multicolumn{3}{|c|}{ Total hours } & \multicolumn{3}{|c|}{ Number of workers } & \multicolumn{2}{|c|}{ Individual hours } \\
\hline & $\ln w^{a}{ }_{m}$ & $\overline{\ln w}^{a}$ & $\ln w_{p}^{a}$ & $\ln w^{a}{ }_{m}$ & $\overline{\ln w}^{a}$ & $\ln w_{p}^{a}$ & $\ln w^{a}{ }_{i}$ & $\ln w^{a}{ }_{i p}$ \\
\hline \multicolumn{9}{|c|}{ White - collar workers } \\
\hline \multicolumn{9}{|c|}{ Observed } \\
\hline \multirow[t]{2}{*}{$\beta$} & 0.1810 & 0.1659 & -0.6451 & 0.3233 & 0.2255 & -0.4982 & -0.0567 & -0.0448 \\
\hline & 0.0519 & 0.0532 & 0.1882 & 0.0518 & 0.0521 & 0.1949 & 0.0018 & 0.0046 \\
\hline $\mathrm{R}^{2}$ & 0.179 & 0.178 & 0.179 & 0.212 & 0.202 & 0.196 & 0.118 & 0.047 \\
\hline \multicolumn{9}{|l|}{ Legal } \\
\hline \multirow[t]{2}{*}{$\beta$} & 0.1827 & 0.1683 & -0.5198 & 0.3258 & 0.2282 & -0.3628 & -0.0569 & -0.0482 \\
\hline & 0.0519 & 0.0532 & 0.1882 & 0.0519 & 0.0521 & 0.1911 & 0.0018 & 0.0046 \\
\hline $\mathrm{R}^{2}$ & 0.179 & 0.178 & 0.177 & 0.212 & 0.202 & 0.194 & 0.119 & 0.048 \\
\hline Nobs. & & 1714 & & & 1714 & & 130 & 97 \\
\hline \multicolumn{9}{|c|}{ Blue-collar workers } \\
\hline \multicolumn{9}{|c|}{ Observed } \\
\hline \multirow[t]{2}{*}{$\beta$} & -0.1300 & -0.0555 & -2.2821 & 0.1406 & -0.0319 & -2.3043 & -0.0381 & 0.0004 \\
\hline & 0.1217 & 0.1326 & 0.3880 & 0.1184 & 0.1314 & 0.3806 & 0.0041 & 0.0118 \\
\hline $\mathrm{R}^{2}$ & 0.183 & 0.181 & 0.230 & 0.1838 & 0.182 & 0.234 & 0.073 & 0.063 \\
\hline \multicolumn{9}{|l|}{ Legal } \\
\hline \multirow[t]{2}{*}{$\beta$} & -0.1322 & -0.0553 & -2.2682 & 0.1511 & -0.0311 & -2.3206 & -0.0408 & 0.0110 \\
\hline & 0.1249 & 0.1382 & 0.3984 & 0.1215 & 0.1368 & 0.3911 & 0.0043 & 0.0124 \\
\hline $\mathrm{R}^{2}$ & 0.183 & 0.181 & 0.227 & 0.184 & 0.182 & 0.232 & 0.073 & 0.063 \\
\hline Nobs. & \multicolumn{3}{|c|}{692} & \multicolumn{3}{|c|}{692} & \multicolumn{2}{|c|}{5413} \\
\hline \multicolumn{9}{|c|}{$\ln w_{m}:$ Log of the Average Firm-level Wage (Firms' sample) } \\
\hline \multirow{2}{*}{\multicolumn{9}{|c|}{$\begin{array}{l}\overline{\ln w}: \text { Firm-level Average of Log-Wage (Workers' sample) } \\
\overline{\ln w_{p}}: \text { Average Firm-level predicted Log-Wage (Workers' sample) }\end{array}$}} \\
\hline & & & & & & & & \\
\hline \multicolumn{9}{|c|}{$\ln w_{i}:$ Log of the Individual Wage (Workers' sample) } \\
\hline
\end{tabular}

In these regressions, explanatory variables besides labor costs are dummy variables indicating location, whether there is a union in the firm, and sector of activity. These variables capture differences in capital prices across regions, labor relations across firms, and technologies across industrial sectors. Exogenous sources of variation for endogeneity 
correction are workers' age, tenure, and gender. Further details on the first stage wage regressions, Eqs. (2), and their explanatory variables, are given in Appendix A3.

Both for white- and blue-collars, when employment is firms' employment measured by hours of work or by the number of workers, an estimation that accounts for endogeneity yields a larger labor cost elasticity of labor demand than one that is done by simple OLS, which suggests the existence of positive assortative matching between firms and workers. When employment is measured by individual hours of work, correcting for endogeneity reduces the labor cost elasticity of labor demand, implying negative assortative matching of workers and firms' individual hours of work. In sum, more productive workers are matched to firms that are larger, in terms of total hours worked and number of employees, and in which working time is shorter.

It is also noteworthy that the labor cost elasticity of the firm-level labor demand is larger for blue-collar than for white-collar workers: measured by total hours it is -0.65 for white-collars and -2.31 for blue-collars; measured by the number of workers it is -0.51 for white-collars and -2.31 for blue-collars. In contrast, the individual hours labor demand has an elasticity of -0.05 for white-collars and 0.00 for blue-collars.

For white-collar workers there is no big difference in estimating by OLS the total labor cost elasticity with the reported or the constructed firm average wage ( $\ln w_{m}$ and $\left.\overline{\ln w}\right)$. The sign, however, in both of these estimations is wrong and only becomes negative once endogeneity is corrected for. Using legal rather than observed non-labor costs produces an underestimation of the labor cost elasticity of employment as measured by total hours of work or number of workers, although this underestimation is lower once a correction for endogeneity is introduced. For individual hours of work, using legal rather than observed labor costs leads to a slight overestimation of this elasticity, though both yield very low values.

For blue-collar workers, estimating the labor cost elasticity by OLS with the reported or the constructed firm average wage ( $\ln w_{m}$ and $\overline{\ln w}$ ) yields substantially different results. Estimating the total labor cost elasticity correcting for endogeneity yields very high values for employment measured by total hours and number of workers. The labor cost employment elasticity measured by total hours is underestimated when legal instead of observed non- 
wage labor costs are used; however, it is slightly overestimated when employment is measured by the number of workers. The labor cost elasticity of employment measured by individual hours has the wrong sign, its value is very small and in many cases nonsignificant. As with white-collars, using legal rather than observed labor costs implies a slight overestimation of the labor elasticity of demand.

In sum, estimations of the firm-level labor demand that are corrected for endogeneity generate large labor costs employment elasticities, especially for blue-collar workers. The opposite is true for the corresponding individual labor demand estimations, where corrections for endogeneity lower labor cost employment elasticities, especially for blue-collars.

In the next section, we use these estimated elasticities to forecast the employment and deadweight loss effects of non-wage labor costs.

\section{EMPLOYMENT EFFECTS OF NON-WAGE LABOR COSTS}

In this section, we predict the percentage employment variation produced by removing non-wage labor costs fully, that is, the effects of eliminating

1. employer-paid non-labor costs: $\Delta \hat{\ln } L=-\hat{\beta} \times \overline{\ln (1+a)}$

2. worker-paid non-labor costs: $\Delta \hat{\ln } L=\hat{\beta} \times \overline{\ln (1-d)}$

3. both employer-and worker-paid non-labor costs: $\Delta \hat{\ln } L=-\hat{\beta} \times[\overline{\ln (1+a)}-\overline{\ln (1-d})]$ 
Table 3. Employment effects of removing employers', workers', and both contributions. Standard errors in small fonts

\begin{tabular}{|c|c|c|c|c|c|c|c|c|}
\hline & \multicolumn{3}{|c|}{ Total hours } & \multicolumn{3}{|c|}{ Number of workers } & \multicolumn{2}{|c|}{ Indiv. hours } \\
\hline & $\ln w^{a}{ }_{m}$ & $\overline{\ln w}^{a}$ & $\ln w_{p}^{a}$ & $\ln w^{a}{ }_{m}$ & $\overline{\ln w}^{a}$ & $\ln w_{p}^{a}$ & $\ln w^{a}{ }_{i}$ & $\ln w_{i p}^{a}$ \\
\hline \multicolumn{9}{|c|}{ White-collar workers } \\
\hline \multicolumn{9}{|c|}{ Employer } \\
\hline \multirow[t]{2}{*}{ Observed } & -1.76 & -1.62 & 6.26 & -3.14 & -2.20 & 4.86 & 0.55 & 0.44 \\
\hline & 0.00 & 0.00 & 0.04 & 0.00 & 0.00 & 0.04 & 0.00 & 0.00 \\
\hline \multirow[t]{2}{*}{ Legal } & -2.47 & -2.27 & 6.99 & -4.40 & -3.08 & 4.90 & 0.77 & 0.65 \\
\hline & 0.00 & 0.01 & 0.06 & 0.00 & 0.00 & 0.07 & 0.00 & 0.00 \\
\hline \multicolumn{9}{|l|}{ Worker } \\
\hline \multirow[t]{2}{*}{ Observed } & -3.29 & -2.72 & 10.51 & -5.87 & -3.69 & 8.16 & 0.93 & 0.73 \\
\hline & 0.02 & 0.02 & 0.29 & 0.05 & 0.03 & 0.21 & 0.00 & 0.00 \\
\hline \multirow[t]{2}{*}{ Legal } & -3.85 & -3.39 & 10.42 & -6.86 & -4.59 & 7.30 & 1.15 & 0.97 \\
\hline & 0.03 & 0.02 & 0.24 & 0.07 & 0.03 & 0.20 & 0.00 & 0.00 \\
\hline \multicolumn{9}{|c|}{ Employer and Worker } \\
\hline \multirow[t]{2}{*}{ Observed } & -5.04 & -4.34 & 16.76 & -9.01 & -5.89 & 13.02 & 1.48 & 1.17 \\
\hline & 0.02 & 0.02 & 0.29 & 0.05 & 0.03 & 0.22 & 0.00 & 0.00 \\
\hline \multirow[t]{2}{*}{ Legal } & -6.31 & -5.66 & 17.42 & -11.26 & -7.67 & 12.19 & 1.91 & 1.62 \\
\hline & 0.03 & 0.02 & 0.25 & 0.07 & 0.03 & 0.21 & 0.00 & 0.00 \\
\hline \multicolumn{9}{|c|}{ Blue-collar workers } \\
\hline \multicolumn{9}{|l|}{ Employer } \\
\hline \multirow[t]{2}{*}{ Observed } & 1.33 & 0.57 & 23.45 & -1.43 & 0.33 & 23.68 & 0.39 & 0.00 \\
\hline & 0.02 & 0.02 & 0.98 & 0.02 & 0.02 & 0.99 & 0.00 & 0.00 \\
\hline \multirow[t]{2}{*}{ Legal } & 1.78 & 0.75 & 30.61 & -2.04 & 0.42 & 31.32 & 0.55 & -0.15 \\
\hline & 0.03 & 0.03 & 0.29 & 0.03 & 0.03 & 0.28 & 0.00 & 0.00 \\
\hline \multicolumn{9}{|l|}{ Worker } \\
\hline \multirow[t]{2}{*}{ Observed } & 1.67 & 0.70 & 28.84 & -1.80 & 0.40 & 29.12 & 0.48 & 0.00 \\
\hline & 0.03 & 0.03 & 0.81 & 0.02 & 0.03 & 0.82 & 0.00 & 0.00 \\
\hline \multirow[t]{2}{*}{ Legal } & 1.87 & 0.80 & 32.69 & -2.14 & 0.45 & 33.44 & 0.59 & -0.16 \\
\hline & 0.03 & 0.04 & 0.92 & 0.03 & 0.04 & 0.93 & 0.00 & 0.00 \\
\hline \multicolumn{9}{|c|}{ Employer and Worker } \\
\hline \multirow[t]{2}{*}{ Observed } & 2.99 & 1.27 & 52.29 & -3.24 & 0.73 & 52.80 & 0.87 & -0.01 \\
\hline & 0.03 & 0.03 & 1.27 & 0.03 & 0.03 & 1.28 & 0.00 & 0.00 \\
\hline \multirow[t]{2}{*}{ Legal } & 3.66 & 1.54 & 63.30 & -4.18 & 0.87 & 64.76 & 1.14 & -0.31 \\
\hline & 0.13 & 0.15 & 2.06 & 0.12 & 0.15 & 2.06 & 0.00 & 0.00 \\
\hline
\end{tabular}

$\ln w_{m}:$ Log of the Average Firm-level Wage (Firms' sample)

$\overline{\ln w}$ : Firm-level Average of Log-Wage (Workers' sample)

$\overline{\ln w_{p}}$ : Average Firm-level predicted Log-Wage (Workers' sample)

$\ln w_{i}$ : Log of the Individual Wage (Workers' sample)

$\ln w_{i p}$ : Log of the Predicted Individual Wage (Workers' sample). 
We perform these exercises ${ }^{14}$ using both observed and legal non-wage labor costs and their associated estimated elasticities computed in the previous section, for the three measures of employment by total hours, number of workers, and individual hours. The results are reported in Table 3 and show that the largest employment effects are obtained from reducing workers' non-wage labor costs, especially for white-collar workers. For white-collar workers removing employer-paid non-wage labor costs increases firm-level total hours of work by around $6 \%$ and the number of workers by $5 \%$, while removing workers' paid non-wage labor costs increases hours of work by $11 \%$ and the number of workers by $8 \%$. The elimination of both non-wage labor costs increases total hours by $17 \%$ and the number of workers by $13 \%$. Thus, employment effects for white-collars are larger for total hours than for number of workers. For individual hours effects are small but significant and positive: around $1 \%$ increase.

For blue-collar workers, employment effects are similar for total hours and for the number for workers and much larger than for white-collars: $24 \%$ for removing employers' contributions and $29 \%$ for removing workers' contributions, so that the employment effect of removing both contributions is $53 \%$. For blue-collar workers individual hours effects are not significantly different from zero.

Using legal rather than observed non-wage labor costs introduces an important overestimation of the employment effects for blue-collar workers, measured by total hours, number of workers, or individual hours. For white-collar workers the differences between legal and observed employment effects are less pronounced. There is also an overestimation of employment variations when using legal non-wage labor costs for total and individual hours, but an underestimation for the number of workers.

Hence, the employment losses provoked by both employers' and workers' contributions are shown to be substantial, especially for blue-collar workers. Estimations that do not correct for endogeneity would have found positive significant employment increases for white-collars and negligible increases for blue-collars, concluding thereby that non-wage labor costs had very little effect in stimulating employment, as it is the case in most of the

14 Notice that these predicted employment variations assume a constant elasticity of demand, that is, they are a linear approximation of the employment effects and are thus less accurate, the larger the labor cost variation. 
literature on this subject. In the next section, we compute the deadweight losses associated with these employment effects.

\section{DEADWEIGHT LOSSES OF NON-WAGE LABOR COSTS}

In this section we compute the deadweight loss effects of employers' and workers' contributions. We estimated the model $\Delta \hat{\ln } L_{i}=\beta \ln w_{i}^{a}+A_{i}$, where $A_{i}=X_{i} \delta$ are the employment effects of all other regressors; that is, the level of employment is $L=A w^{\beta}$. We have two wage levels, $w_{1}$ and $w_{0}\left(w_{1}>w_{0}\right)$, which imply employment levels $L_{1}=A w_{1}{ }^{\beta}$ and $L_{0}=A w_{0}{ }^{\beta}$, respectively. Contribution revenues are then $R=\left(w_{1}-w_{0}\right) L_{1}>0$, and the deadweight loss area comes from integrating:

$$
I=\int_{w_{0}}^{w_{1}} A x^{\beta} d x-R_{1}=\frac{w_{1} L_{1}-w_{0} L_{0}}{\beta+1}-R
$$

In Appendix 4, we give further details on this computation (See also Auerbach and Hines (2002). One can also approximate the deadweight loss, as it is usually done, by a (Harberger) triangle:

$$
T=\frac{\left(w_{1}-w_{0}\right)\left(L_{0}-L_{1}\right)}{2}
$$

Figure 3 illustrates the deadweight loss area $\mathrm{T}$ and the contribution revenues $\mathrm{R}$, when there are both employer's contributions, which shift the labor demand downward, and worker's contribution, which shift the labor supply upward 
Figure 3: Deadweight Loss of employers' and workers' contributions

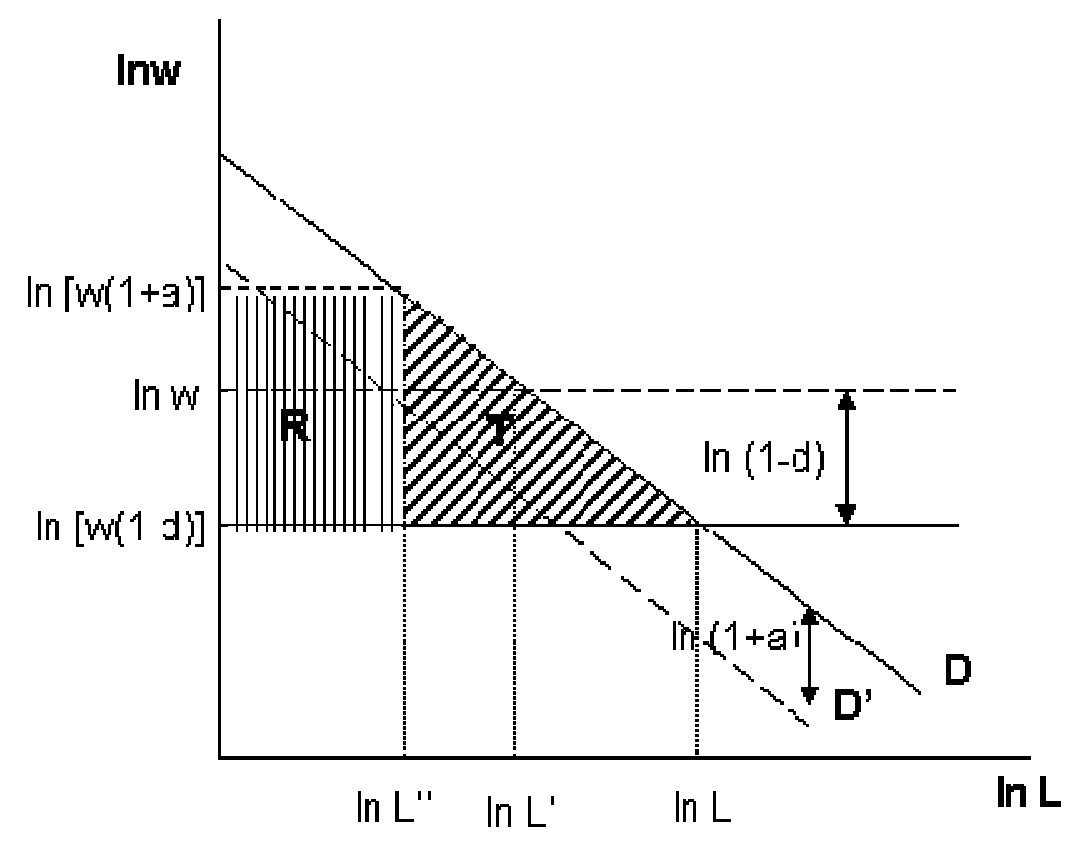

Then, wage levels $w_{1}$ and $w_{0}$ are then defined for

1. employers' contributions: $w_{1}=w(1+a), w_{0}=w$

2. workers' contributions: $w_{1}=w, w_{0}=w(1-d)$

3. both workers' and employers' contributions: $w_{1}=w(1+a), w_{0}=w(1-d)$

Table 4 reports the estimated deadweight losses of eliminating workers' and employers' contributions, using different measures of employment, of contributions, and of deadweight losses, for white-collar and for blue-collar workers, respectively. As with employment effects deadweight losses are larger for workers' than for employers' contributions for both occupational categories, and larger for blue-collar than for white-collar workers. For white-collars deadweight losses of observed employers' contributions are 5.6\% of contribution revenues; of observed workers' contributions they are $3.2 \%$ of contribution revenues, when measured by total hours. For blue-collars deadweight losses of observed employers' contributions are $12.5 \%$ of contribution revenues; of observed workers' contributions they are $16.1 \%$ of contribution revenues, when measured by total hours. For blue-collar workers deadweight losses are practically identical when employment is 
measured by the number of workers. For white-collar workers, deadweight losses are $2.5 \%$ of contribution revenues for employers' contributions and 4\% for workers' contributions. For individual hours effects are very small for white-collar workers and, as employment effects, appear with the wrong sign for blue-collar workers.

Table 4: Estimated Deadweight loss of Employer, Worker and both Contributions as a Percentage of Contribution Revenues

\begin{tabular}{|c|c|c|c|c|c|c|}
\hline \multirow{2}{*}{ Contribution } & \multicolumn{2}{|c|}{ Total Hours } & \multicolumn{2}{|c|}{ Number of Workers } & \multicolumn{2}{|c|}{ Individual Hours } \\
\hline & Integral & Triangle & Integral & Triangle & Integral & Triangle \\
\hline \multicolumn{7}{|c|}{ White-collar workers } \\
\hline \multicolumn{7}{|c|}{ Employer } \\
\hline Observed & 3.14 & 3.23 & 2.44 & 2.50 & 0.22 & 0.22 \\
\hline Legal & 3.50 & 3.62 & 2.43 & 2.51 & 0.32 & 0.33 \\
\hline \multicolumn{7}{|l|}{ Worker } \\
\hline Observed & 5.59 & 5.90 & 3.88 & 4.06 & 0.36 & 0.37 \\
\hline Legal & 5.15 & 5.47 & 3.41 & 3.58 & 0.47 & 0.49 \\
\hline \multicolumn{7}{|c|}{ Employer and Worker } \\
\hline Observed & 8.77 & 9.51 & 6.31 & 6.76 & 0.56 & 0.59 \\
\hline Legal & 8.64 & 9.49 & 5.79 & 6.27 & 0.77 & 0.82 \\
\hline \multicolumn{7}{|c|}{ Blue-collar workers } \\
\hline \multicolumn{7}{|c|}{ Employer } \\
\hline Observed & 12.51 & 13.35 & 12.33 & 13.13 & -0.00 & -0.00 \\
\hline Legal & 17.02 & 18.39 & 16.59 & 17.91 & -0.01 & -0.01 \\
\hline \multicolumn{7}{|l|}{ Worker } \\
\hline Observed & 15.77 & 17.02 & 15.85 & 17.12 & -0.00 & -0.00 \\
\hline Legal & 18.26 & 19.96 & 18.65 & 19.19 & -0.08 & -0.08 \\
\hline \multicolumn{7}{|c|}{ Employer and Worker } \\
\hline Observed & 30.37 & 34.94 & 30.25 & 34.84 & -0.00 & -0.00 \\
\hline Legal & 38.55 & 45.69 & 37.21 & 43.96 & -0.15 & -0.15 \\
\hline
\end{tabular}

For white-collar workers deadweight losses, both in terms of total hours and the number of workers, are somewhat larger when measured by observed rather than by legal non-wage labor costs. For blue-collar workers, they are substantially smaller for the observed non-wage labor costs both when using total hours and the number of workers.

Thus, there are not only substantial employment losses but also large deadweight losses of mandated employers' and workers' contributions, especially for blue-collar workers. 


\section{EMPLOYMENT AND DEADWEIGHT LOSSES OF COMPLYING WITH LEGAL CONTRIBUTIONS}

In this section we analyze the employment and deadweight loss effects of adjusting observed non-wage labor costs to their legal level.

Table 5: Employment effects of undercomplying with legal non-wage labor costs. Standard errors in small fonts

\begin{tabular}{lccc}
\hline \multicolumn{1}{c}{ Contribution } & Total hours & Number of workers & Individual hours \\
\hline \hline White-collar workers & & & \\
Employer & 2.40 & 1.86 & 0.17 \\
& 0.01 & 0.01 & 0.00 \\
Worker & 2.40 & 1.86 & 0.17 \\
& 0.13 & 0.08 & 0.00 \\
Employer and worker & 4.79 & 3.72 & 0.33 \\
& 0.13 & 0.08 & 0.00 \\
Blue-collar workers & & & \\
Employer & 7.35 & 7.42 & 0.00 \\
& 0.70 & 0.71 & 0.00 \\
Worker & 4.05 & 4.09 & 0.00 \\
& 0.81 & 0.82 & 0.00 \\
Employer and worker & 11.40 & 11.51 & 0.00 \\
& 1.07 & 1.09 & \\
\hline \hline
\end{tabular}

What is the employment effect of firms not fully complying with paying employers' and workers' contributions? Because of under-compliance, the actual labor cost incurred by firms is lower than the stipulated legal one. Table 5 reports the effects of not complying with legal contributions on employment measured by total hours worked at the firm level, the number of workers by firm, and individual hours. For white-collar workers the effect of not complying with legal workers' contributions is about the same as the effect of not complying with employers' contributions, $2.42 \%$ for total hours, $1.90 \%$ for the number of workers, and $0.17 \%$ for individual hours. The total effect of not complying with these two contributions amounts to $4.83 \%$ for total hours, $3.81 \%$ for the number of workers, and $0.34 \%$ of individual hours.

For blue-collar worker the picture is somewhat different, as the employment effect of not complying with the employers' contributions is larger than the effect of not complying with the workers' contributions. Moreover, since the labor cost elasticity is large, the employment effects are much larger than for white-collar workers. As one would expect 
because of the low labor costs individual hours elasticities, for blue-collar workers the effect in individual hours is negligible. Both for employment measured as total hours of work or the number of workers, employment effects of not complying with employers' contributions is around $7.5 \%$, and it is around $4.1 \%$ for not complying with workers' contributions. Thus, the effect of not complying with both contributions is around $11.6 \%$. As shown in the previous sections, variations in the individual hours margin induced by labor costs variations is somewhat important only for white-collar workers, not for blue-collars.

Table 6: Deadweight loss of complying with Employer, Worker and both legal contributions as a percentage of contribution Revenues

\begin{tabular}{lcccccc}
\hline \hline \multirow{2}{*}{ Contribution } & \multicolumn{2}{c}{ Total hours } & \multicolumn{2}{c}{ Number of workers } & \multicolumn{2}{c}{ Individual hours } \\
& Integral & Triangle & Integral & Triangle & Integral & Triangle \\
\hline \hline White-collar workers & & & & & & \\
Employer & 1.21 & 1.24 & 0.89 & 0.91 & 0.08 & 0.08 \\
Worker & 0.93 & 0.98 & 1.16 & 1.19 & 0.08 & 0.08 \\
Employer and Worker & 2.13 & 2.20 & 2.05 & 2.11 & 0.16 & 0.17 \\
& & & & & & \\
Blue-collar workers & & & & & & \\
Employer & 4.02 & 4.20 & 3.94 & 4.10 & 0.00 & 0.00 \\
Worker & 1.98 & 2.08 & 2.22 & 2.31 & 0.00 & 0.00 \\
Employer and Worker & 6.01 & 6.30 & 6.22 & 6.50 & 0.00 & 0.00 \\
\hline \hline
\end{tabular}

In Table 6 we show the deadweight losses resulting from complying fully with the legal level of non-wage labor costs. ${ }^{15}$ As in the previous section, we compute them both as an integral and simply as a triangle. For white collar workers, the deadweight loss of both employer's and worker's contributions measured as total hours or as the number of workers is around $2 \%$ of contribution revenues, split almost evenly between the two. For blue collar workers, the deadweight loss represents around $6 \%$ of contribution revenues, again for both contributions and measured as total hours or the number of workers. Once again, individual hours of blue collar workers are not reactive to labor costs variations; consequently deadweight losses are smaller than for white-collars.

In sum, judging from its implied employment and deadweight losses, undercompliance is substantial. Employment losses of compliance with mandated

15 In Appendix A5 we provide some details on the computation of the deadweight losses of undercompliance with legal contributions. 
employers' and workers contributions are $4 \%$ for white-collars and $12 \%$ for blue-collars, with respective associated deadweight losses of $2 \%$ and $6 \%$ of contribution revenues.

\section{CONCLUSIONS}

Using a matched firm-workers dataset we have shown that an estimation that accounts for endogeneity of wages yields a larger labor cost elasticity of a long run, unconditional labor demand than one obtained by OLS. We explain that this result is evidence for positive assortative matching between firms and workers: larger firms are matched with more productive workers. We find that employer's and worker's paid nonwage labor costs reduce employment by $17 \%$ for white-collars and by $53 \%$ for blue-collars. The associated deadweight loss of these non-wage labor costs are $9 \%$ of contribution revenues for white-collar workers and $31 \%$ of contribution revenues for blue-collars. Significant increases of individual hours only occur for white-collar, not for blue-collar workers, that is, white-collars exhibit a larger labor costs elasticity of demand for individual hours than blue-collars.

On the other hand, estimating labor costs employment elasticities using nonwage labor costs measured in the available datasets rather using legally established rules yields substantially different results only for white-collar workers, for which undercompliance with legal contributions is larger than for blue-collars. Furthermore, we compute the employment effects of undercomplying with the mandated employers' and workers contributions. Because of undercompliance employment is $4 \%$ larger for white-collars and $12 \%$ larger for blue-collars. The deadweight loss of complying with mandated contribution is $2 \%$ for whitecollars and $6 \%$ of contribution revenues for blue-collars.

These results show large employment and, often ignored, deadweight losses of both mandated employer's and worker's contributions and are thus encouraging of policies to increase job creation by lowering non-wage labor costs. 


\section{APPENDIX}

\section{A1. Labor reforms in Peru in the nineties}

According to Saavedra (2000), labor laws were very restrictive, protectionist and cumbersome. In the early nineties Peru went through a process of 'structural' reforms that were intended to make labor markets more flexible.

Blue-collars and White-Collars.- Before the reform there was a strong distinction between white- and blue-collar workers, so that firms had to have different payrolls with different payment frequencies for these two types of workers: blue-collars were paid on a weekly basis, while white-collars on a monthly basis. Blue-collars had more benefits than whitecollars, which reduced the relative hiring of blue-collars. (Chacaltana 1999). The reform eliminated the strong distinction between them, so that both are considered workers with same severance payments and other benefits. Firms are also free to choose the frequency of payment to their workers.

Firing costs.- Up to the 1990 workers in Peru enjoyed absolute stability at the workplace, a right that was protected by the Constitution. The labor reform changed this completely by introducing the 'unfair' firing, that is, workers can be fired without any justification, just receiving a severance payment. In 1996, after several changes, firing costs for unfair dismissals were established at one and a half monthly wages for every year employed the firm, with a ceiling of twelve wages. The reform also extended 'fair' dismissals to include workers' bad conduct and low productivity, and introduced technological, economic and structural reasons as valid causes for collective layoffs, that is, dismissals of no less than $10 \%$ of the workforce.

Temporary Contracts.- Before the reforms a temporary contracts required written authorization by the Ministry of Labor, had a maximum duration of one year and were renewable only for one year. The labor reform allowed temporary contracts of several durations and without any authorization by the government. Workers under these contracts have the same benefits than workers with contracts of undetermined duration; however, if the employer fires a worker before the term of the contract, the firing cost of the permanent contract applies. These contracts can be of one year, with a maximum renovation of five years. The law also allowed temporary contracts for a specific work or service of a determined duration and with different frequencies. 
These labor reforms made the labor markets more flexible, by eliminating absolute job stability, reducing firing costs, and allowing temporary contracts without any duration restriction. They also simplified payroll management by equalizing white and blue-collar workers.

\section{A2. Legal non-wage labor costs}

On top of the basic workers receive wage several additional bonuses, which are subject to employers' contributions and workers' deductions. In this study, the additional wage is already included as part of the total wage. These additional concepts of wages add up to $54.08 \%$ of the basic wage:

Additional wages as a percentage of basic wages. June 2004

\begin{tabular}{lr}
\hline \hline Additional Concepts of Wages \% of basic wage \\
\hline
\end{tabular}

Additional wages include payments that should cover for weekends (DSO, Descanso semanal obligatorio), non-working holidays (FNL, Feriados no laborables), and bonuses that are related to the number of family members (family assignments). Besides, workers receive two extra monthly wages every year as Christmas and National Holiday bonuses called Gratificaciones. Vacations are paid holidays that last 30 days per year worked for the same employer. The tenure bonus (CTS, Compensación por Tiempo de Servicios) is an additional wage payment for every tenure year of the worker.

Employer's contributions in Peru amount to $14.45 \%$ of the basic wage and consists of the following concepts: 
Employer's contribution as a percentage of basic wages. June 2004

\begin{tabular}{lr}
\hline \hline Employer's contributions \% of wage & \\
\hline \hline & \\
Health Plan Payments & 9.00 \\
Solidarity Extraordinary Tax & 1.70 \\
Manufacturing Training Fund & 0.75 \\
Accident Insurance & 3.00 \\
Total Employer's Contributions & $\mathbf{1 4 . 4 5}$ \\
\hline
\end{tabular}

Health Plan Payments represent $9 \%$ of the basic wage, of which $6.75 \%$ is for the public system (ESSALUD, Seguro Social de Salud) and 2.25\% goes to the private system (EPS, Empresas Prestadoras de Salud), if the worker has a private health insurance. Otherwise, the whole contribution goes to the public system.

The Solidarity Extraordinary Tax (IES, Impuesto Extraordinario de Solidaridad) was created in 1998 to replace mandatory contributions to finance housing, National Housing Fund (FONAVI, Fondo Nacional de Vivienda). Initiallly, it amounted to $2 \%$ of the basic wage., but then went down to $1.7 \%$.

Manufacturing Training contributions (SENATI, Servicio Nacional de Adiestramiento en Trabajo) only apply to some industrial firms (Category D of SIC). From 1994 onwards they have been going down from $1.5 \%$ to become, in 1997, $0.75 \%$ of the basic wage. Accident Insurance (SCTR, Seguro Complementario de Trabajo de Riesgo) is on average 3\% of the basic wage.

Workers' deductions consist of income taxes and social security contributions and vary depending on the wage level and on whether the pension system is private or public:

Workers' deductions, Income Tax +Social Security, as a percentage of basic wages. June 2004

\begin{tabular}{|c|c|c|c|}
\hline \multicolumn{2}{|c|}{ Workers' Deductions } & \multicolumn{2}{|c|}{ Pension System Contributions \% } \\
\hline Wage & Income & Private & Public \\
\hline Bracket & Tax \% & 11.19 & 13.00 \\
\hline 0-7 UIT & 0.00 & 11.19 & 13.00 \\
\hline 7 -27 UIT & 11.00 & 22.19 & 24.00 \\
\hline 27-54 UIT & 16.00 & 27.19 & 29.00 \\
\hline +54 UIT & +16.00 & +27.19 & +29.00 \\
\hline
\end{tabular}


Employers retain income taxes and mandatory social security contributions from workers' wages. For wage levels below 7 Tax Units (UIT, Unidad Impositiva Tributaria), there is no retention, Tax Units are monetary amounts fixed by the government, and updated from time to time. On June 2004, the UIT was S/. 3,200. From 7 UIT onwards employers have to make income tax deductions on workers' payments: the lowest rate is $15 \%$ while the highest reach $30 \%$. The amount of social security contributions differs depending on the type of system. In the public pension system the contribution is $13 \%$. In the private pension system the mandatory fixed contribution rate is $8 \%$, the maintenance fee is on average $2.27 \%$, and the insurance fee is on average $0.92 \%$, totalling to $11.19 \%$.

\section{A3. Wage regressions}

In Table A1 we report the wage regressions, the first stage of our estimation of the labor demand elasticity. These are Mincer regressions done for white- and blue-collars, both for weekly and hourly wages, and for take-home wages using observed and legal workers deductions. Unfortunately, in the dataset we do not have workers' education, which would make our regression a typical Mincer regression. However, we have age (which proxies potential experience) and tenure, as well as gender, union status, city of residence (Lima vs. other), and industrial sector.

Both returns to age and to tenure are larger for white-collars than for blue-collars. However, while returns to age are larger than returns to tenure for white-collars, the opposite is true for blue-collars, returns to tenure are larger than returns to age. Among blue-collars gender wage differences are more pronounced than among white-collars. For blue-collars male workers earn around $20 \%$ more than their female counterparts. Among white-collars males earn around $7 \%$ more in weekly wages, but $3 \%$ more in hourly wage, than female workers. This difference may be due to the lower amount of hours worked by female white-collar workers. The effect of being unionized is to increase wages by around $25 \%$ for white-collars and by around $21 \%$ for blue-collars. Working in Lima, the capital of Peru, means a differential of more than $50 \%$ in white-collar wages and of $20 \%$ of blue-collar wages, over working in other cities. 
Table A1: Wage regressions. Dummies for Industrial Sectors are used but not reported Standard errors in small fonts

\begin{tabular}{lcccccccc}
\hline \hline & \multicolumn{4}{c}{ White-collars } & \multicolumn{4}{c}{ Blue-collars } \\
\cline { 2 - 10 } & \multicolumn{3}{c}{ Wage } & \multicolumn{2}{c}{ Hourly wage } & \multicolumn{2}{c}{ Wage } & \multicolumn{2}{c}{ Hourly wage } \\
\cline { 2 - 9 } & Obs. & Legal & Obs. & Legal & Obs. & Legal & Obs. & Legal \\
\hline \hline Age & 0.0775 & 0.0761 & 0.0805 & 0.791 & 0.0180 & 0.0178 & 0.0180 & 0.0178 \\
& 0.0047 & 0.004 & 0.0047 & 0.0045 & 0.0045 & 0.0042 & 0.0044 & 0.0042 \\
Age $^{2}$ & -0.0008 & -0.0008 & -0.0008 & -0.0008 & -0.0001 & -0.0001 & -0.0001 & -0.0001 \\
& 0.0001 & 0.0001 & 0.0001 & 0.0001 & 0.0001 & 0.0001 & 0.0001 & 0.0001 \\
Tenure & 0.0348 & 0.0348 & 0.0349 & 0.0349 & 0.0231 & 0.0226 & 0.0212 & 0.0208 \\
& 0.0024 & 0.0023 & 0.0025 & 0.0024 & 0.0026 & 0.0024 & 0.0025 & 0.0024 \\
Tenure & -0.0006 & -0.0006 & -0.0007 & -0.0007 & -0.0003 & -0.0002 & -0.0002 & -0.0002 \\
& 0.0001 & 0.0001 & 0.0001 & 0.0001 & 0.0001 & 0.0001 & 0.0001 & 0.0001 \\
Male & 0.0681 & 0.0663 & 0.0294 & 0.0276 & 0.2285 & 0.2216 & 0.2030 & 0.1960 \\
& 0.0118 & 0.0115 & 0.0123 & 0.0120 & 0.0138 & 0.0134 & 0.0126 & 0.0122 \\
Union & 0.2291 & 0.2246 & 0.2597 & 0.2552 & 0.1939 & 0.1910 & 0.2330 & 0.2301 \\
& 0.0180 & 0.0175 & 0.0184 & 0.0180 & 0.0166 & 0.0160 & 0.0164 & 0.0158 \\
Lima & 0.5300 & 0.5160 & 0.5683 & 0.5543 & 0.2226 & 0.2100 & 0.1966 & 0.1840 \\
& 0.0114 & 0.0119 & 0.0119 & 0.0116 & 0.0132 & 0.0126 & 0.0126 & 0.0120 \\
Constant & 3.5407 & 3.5485 & -0.3719 & -0.3640 & 4.3410 & 4.3331 & 0.6051 & 0.5972 \\
& 0.0968 & 0.0914 & 0.0975 & 0.0925 & 0.0847 & 0.0806 & 0.0829 & 0.0787 \\
$\mathrm{R}^{2}$ & 0.311 & 0.313 & 0.314 & 0.316 & 0.300 & 0.309 & 0.315 & 0.325 \\
\hline \hline
\end{tabular}

\section{A4. Computation of deadweight losses}

The computation of the deadweight areas proceeds in the following way:

$I=\int_{w_{0}}^{w_{1}} A x^{\beta} d x-R=\left.A \frac{x^{\beta+1}}{\beta+1}\right|_{w_{0}} ^{w_{1}}-R=\frac{A}{\beta+1}\left[w_{1}^{\beta+1}-w_{0}^{\beta+1}\right]-R=\frac{w_{1} L_{1}-w_{0} L_{0}}{\beta+1}-R$

Notice that for any value of $\beta$, if $<w_{1}>w_{0}$, then $\frac{A}{\beta+1}\left[w_{1}^{\beta+1}-w_{0}^{\beta+1}\right]>0$.

\section{A5. Deadweight losses of undercomplying with legal contributions}

For computing variations from observed to legal contributions, denoted respectively with the subscript 'obs' and 'legal', wage levels $w_{l}$ and $w_{0}$ are then defined for

1. employers' contributions: $w_{1}=w\left(1+a_{\text {legal }}\right), w_{0}=w\left(1+a_{o b s}\right)$

2. workers' contributions: $w_{1}=w \frac{1-d_{\text {obs }}}{1-d_{\text {legal }}}, w_{0}=w$ 


$$
\begin{aligned}
& \text { 3. both workers' and employers' contributions: } w_{1}=w \frac{1-d_{\text {obs }}}{1-d_{\text {legal }}}\left(1+a_{\text {obs }}\right) \text {, } \\
& w_{0}=w\left(1+a_{o b s}\right)
\end{aligned}
$$

These wage levels are used both in the computation of deadweight losses as integrals and as triangles. 


\section{REFERENCES}

Auerbach, A. J. and Hines, J. J.

2002 Taxation and economic efficiency, in A. J. Auerbach and M. Feldstein, eds, 'Handbook of Public Economics', Vol. 3 of Handbook of Public Economics, Elsevier, chapter 21, pp. 1347-1421.

Bentolila, S. and Bertola, G.

1990 'Firing costs and labor demand: How bad is eurosclerosis?', Review of Economic Studies 57, 381—402.

Chacaltana, J.

1999 Los Costos Laborales en el Perú, in 'Inseguridad Laboral y Competitividad: modalidades de contratación', Oficina Internacional del Trabajo, Lima, pp.205284.

Clark, K. B. and Freeman, R. B.

1980 'How Elastic is the Demand for Labor?', Review of Economics and Statistics 62(4), 509-520.

Freeman, R. B.

2000 Single Peaked vs. Diversified Capitalism: The Relation Between Economic Institutions and Outcomes. NBER Working Paper 7556. Cambridge, United States: National Bureau of Economic Research.

Hamermesh, D.

1986 The Demand for Labor in the Long Run, in O. Ashenfelter and E. R. Layard, eds, 'Handbook of Labor. Economics, Volume', North Holland., Amsterdam, pp. $53-90$.

Hamermesh, D.

1989 'Labor Demand and the Structure of Adjustment Costs', American Economic Review 79(4), 674-689.

Heckman, J. and Pagés-Serra, C.

2000 'The Cost of Job Security Regulation: Evidence from Latin American Labor Markets', Economía 1(1).

Hopenhayn, H. and Rogerson, R.

1993 'Job turnover and policy evaluation', Journal of Political Economy 101(5), 915938.

IPE

1998 Perú: Costos no Salariales y Competitividad (estudio de actualización). Serie de Estudios, Estudio 1998-042. Mayo. Instituto Peruano de Economía (IPE).

Jaramillo, M.

2004 La Regulación del Mercado Laboral en el Perú. Informe de Consultoría. Lima: Grupo de Análisis para el Desarrollo (GRADE). 
Márquez, G. and Pagés-Serra, C.

1998 Ties That Bind: Employment Protection and Labor Market Outcomes in Latin America. Working Paper No 373, Research Department of Inter American Development Bank. Washington D.C.

MTPE

1999 Costos Laborales, Competitividad y Empleo en el Perú. En: Boletín de Economía Laboral (BEL) No 11. Lima: Ministerio de Trabajo y Promoción del Empleo (MTPE).

2004 Costos laborales en el Perú. En: Boletín de Economía Laboral (BEL) No 28 - 29. Lima: Ministerio de Trabajo y Promoción del Empleo (MTPE).

Nickell, S.

1987 Dynamic models of labour demand, in O. Ashenfelter and E. R. Layard, eds, 'Handbook of Labor. Economics', Vol. 1 of Handbook of Labor Economics, Elsevier, Amsterdam, chapter 9, pp. 53-90.

Rendón, S. and Barreto, R.

1992 La demanda laboral en la manufactura peruana. Documento de Trabajo No 1. Lima: ADEC-ATC.

Rendon, S. 2004

Job Creation and Investment in Imperfect Capital and Labor Markets. Working Paper, No. E2004/35. Fundación Centro de Estudios Andaluces.

Roberts, M. J. and Skoufias, E.

1997 'The Long-Run Demand for Skilled and Unskilled Labor in Colombian Manufacturing Plants', Review of Economics and Statistics 79(2), 330-334.

Saavedra, J. and Torero, M.

2000 Labor Market Reforms and their Impact on the Formal Labor Demand and Job Market Turnover: The Case of Peru. Research Network Working Paper No. R394. Washington D.C: Inter-American Development Bank. 